\title{
IDŐJÁRÁS
}

Quarterly Journal of the Hungarian Meteorological Service

Vol. 125, No. 3, July-September, 2021, pp. 477-490

\section{Spatiotemporal distribution of heavy and extreme snowfalls in the Transcarpathian region}

\author{
Ruslan Ozymko ${ }^{1,3 *}$, Alina Semerhei-Chumachenko ${ }^{2}$, and Vasyl Manivchuk ${ }^{3}$ \\ ${ }^{1}$ Uzhhorod National University \\ Narodna Square 3, Uzhhorod, Ukraine \\ ${ }^{2}$ Odesa State Environmental University \\ Lvivska Street, 15, Odesa, Ukraine \\ ${ }^{3}$ Transcarpathian Regional Center of Hydrometeorology \\ Slovianska Embankment, 5, Uzhhorod, Ukraine
}

*Corresponding author E-mail: ruslanozymko@gmail.com

(Manuscript received in final form August 31, 2020)

\begin{abstract}
This paper presents a spatiotemporal analysis of the dynamics of heavy and extreme snowfalls in the Transcarpathian region during 1990-2019. Data on snowfalls are obtained from the observation points of the state hydrometeorological network of the Transcarpathian Regional Center of Hydrometeorology. Also there are data included from the Pozhezhevska snow avalanche station (Ivano-Frankivsk region) as a representative observation point for the highland zone of the eastern part of the Transcarpathian region. The analysis took into account the date of snowfall, the amount of precipitation that fell during the snowfall,l and its duration. The recurrence of different indicators of snowfall distribution was calculated for each observation point separately for the specified thirtyyear period. Some results were mapped by the isolines using kriging interpolation. Spatiotemporal heterogeneities and regularities in the distribution of heavy and extreme snowfalls have been revealed.

Key-words: heavy snowfall, extreme snowfall, Transcarpathian region, recurrence, trend, distribution, kriging interpolation
\end{abstract}




\section{Introduction}

Precipitation is one of the main indicators of climate. In most cases, rainfall is uneven, especially over mountainous areas (Barry, 1984). Natural meteorological phenomena associated with precipitation are characterized by significant variability and discreteness in space and time, which complicates their study (Babychenko, 1991; Lipinskyi et al., 2006; Lohvynov et al., 1972,1973; Sakaly, 1985).

The distribution of precipitation can be extremely uneven both during the year and during one season. This also applies to heavy and extreme snowfalls, of which there may be several cases in one year and dozens in another. At the same time, their intensity, duration, and area of precipitation vary greatly, which complicates weather forecasting and leads to disruptions of various sectors of the national economy and infrastructure (Acar and Gönençgil, 2019; Lukić et al., 2018; Balabukh, 2013; Osadchyy and Babychenko, 2012). All over the world and in Ukraine in particular, the frequency of extreme weather events is increasing, among which heavy and extreme precipitation takes the first place (Balabukh, 2008; Lohvynov et al., 1972; Osadchyy and Babychenko, 2012; Pachaury and Mayer, 2014). That is why scientists raise the issue of long-term dynamics of precipitation, especially in conditions of climate change and increasing frequency of weather anomalies. The policy of governments on climate change has been ratified by many documents at national and international levels (Tykhomyrova, 2018).

Insufficient attention has always been paid to the study of heavy and extreme snowfalls, especially in the Ukrainian Carpathians. The main interest of scientists was limited to heavy and extreme rains, heavy and extreme prolonged rains, as well as heavy and extraordinary showers (Balabukh, 2008; Voloshyna and Knysh, 2010; Pyasetska, 2001; Lukic et al., 2018). The risks and dangers of heavy and extreme snowfalls are significantly underestimated. First of all, such snowfalls are the causes of avalanches and traffic jams. During intensive falling sleet, it often sticks to various surrounding objects, breaking tree branches, breaking power and communication wires, disrupting constructions and utilities. Late snowfalls make it impossible to carry out spring agricultural work (Lipinskyy et al., 2006; Lohvynov et al., 1973; Sakaly, 1985).

The purpose of this work was to analyze the long-term changes in the number, intensity and spatial distribution of heavy and extreme snowfalls in the Transcarpathian region. 


\section{Materials and methods}

\subsection{Research area}

The Transcarpathian region is located in the extreme west of Ukraine. It borders on Lviv and Ivano-Frankivsk regions, as well as four European Union countries: Poland, Slovakia, Hungary, and Romania. The area of the region is 12.8 thousand $\mathrm{km}^{2}(2.1 \%$ of the territory of Ukraine). Thus, the Transcarpathian region is located in Central Europe, which has important cross-border significance (Rishko, 2017).

The Transcarpathian region is a unique ecological system of western Ukraine with a variety of relief and climatic conditions due to the vertical clarity and diversity of landscapes. Its territory is protected from the north and east by the Ukrainian Carpathians, from the northwest by the Tatra Mountains, from the south by the western Romanian mountains and the Maramureş massif (Rishko, 2017; Sakaly, 1985; Lohvynov et al., 1973).

About two thirds of the territory of Transcarpathia is occupied by mountains with the highest peak of Ukraine (Hoverla, 2061 meters above sea level). The region is located on the southwestern slopes of the Ukrainian Carpathians (Eastern Carpathians) and on the adjacent Transcarpathian lowlands, which are part of the Middle Danube lowlands (Herenchuk, 1981).

The climate of Transcarpathia is temperate-continental with sufficient and excessive humidity, unstable spring, not very hot summer, warm autumn, and mild winter. The average annual wind speed in different places is $1.2-2.4 \mathrm{~m} / \mathrm{s}$. The maximum speed, registered in the area of the cities of Khust and Mizhhirya and in the mountain meadows, reaches about $40 \mathrm{~m} / \mathrm{s}$. In January, the average monthly long-term temperature is $-7.8^{\circ} \mathrm{C}$ in the mountains, while in the lowlands (Uzhhorod) it is only $-3.1{ }^{\circ} \mathrm{C}$, and in summer it is $11-14^{\circ} \mathrm{C}$ in the highlands and $20-21{ }^{\circ} \mathrm{C}$ in the lowlands. The amount of precipitation changes depending on the height of the territory. The average annual rainfall is $600-800 \mathrm{~mm}$ in the lowlands, and $1000-1500 \mathrm{~mm}$ in the mountains (in a year of high water content it is up to $2500 \mathrm{~mm}$ ) (Babychenko and Dyachuk, 2003; Sakaly, 1985).

Fig. 1 shows a map of the research area with the geographical location of the observation points of the Ukrainian Hydrometeorological Center, from which data were collected on heavy and extreme snowfall for this work. 


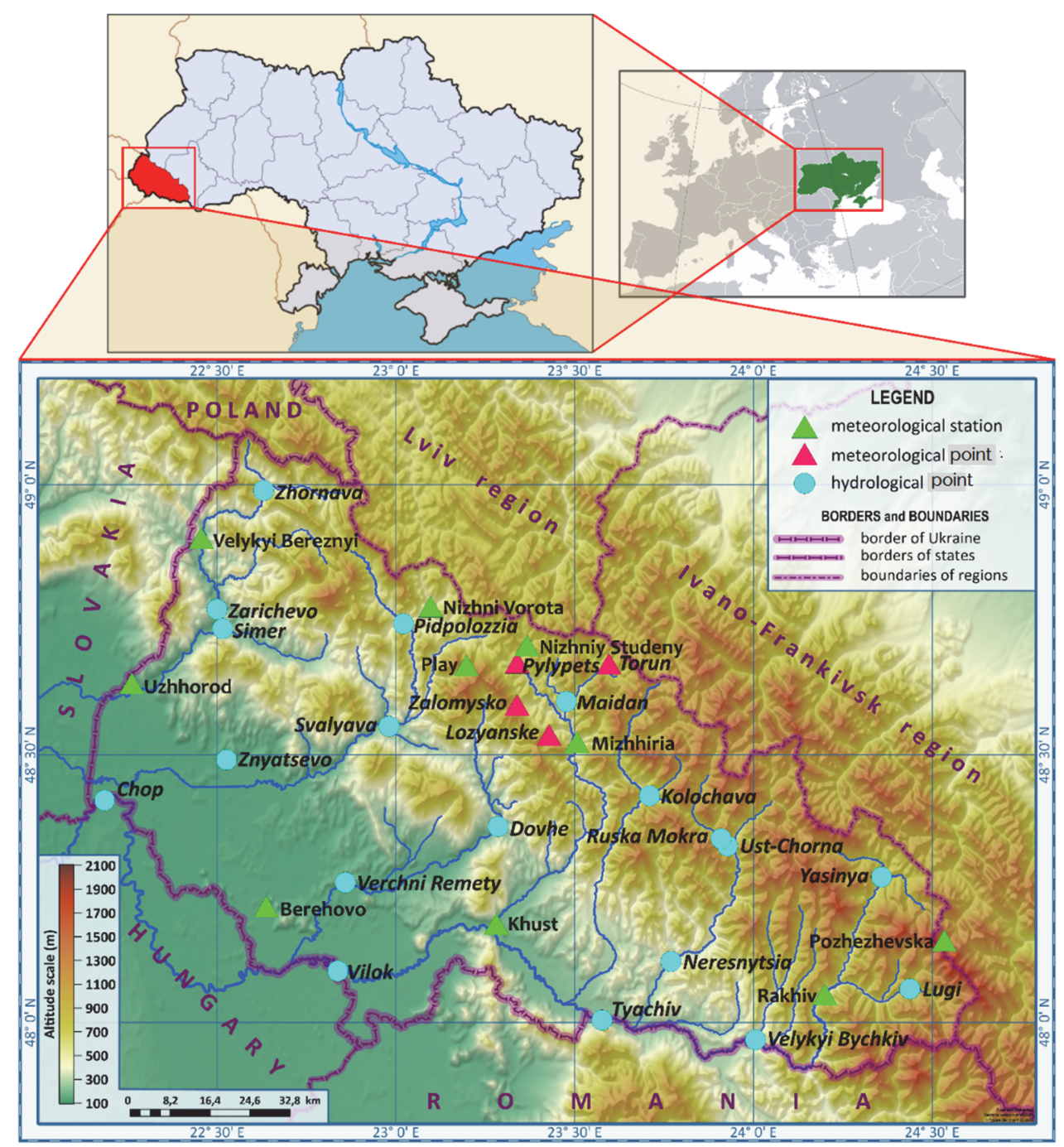

Fig. 1. Geographical location of hydrometeorological observation point involved in the research.

\subsection{Data and methods}

We used data only from those points that conducted continuous meteorological observations of precipitation during 1990-2019 to ensure temporal representativeness. In total, data from 10 meteorological stations, 4 meteorological points and 19 hydrological observation points are included in the work (Table 1).

According to the methodological guidelines of the Central Geophysical Observatory named after Borys Sreznevskyi (CGO) and the Ukrainian Hydrometeorological Center (UkrHMC) a clear criteria is defined for heavy and extreme snowfall (Table 2) (Humonenko et al., 2019). 
Table 1. Lists of points of hydrometeorological observations

\begin{tabular}{|c|c|c|c|}
\hline Name & Latitude (north) & Longitude (east) & Altitude (m) \\
\hline 1. MS Berehovo & $48^{\circ} 13^{\prime} 02^{\prime \prime}$ & $22^{\circ} 38^{\prime} 12^{\prime \prime}$ & 112 \\
\hline 2. MS Uzhhorod & $48^{\circ} 37^{\prime} 58^{\prime \prime}$ & $22^{\circ} 15^{\prime} 39^{\prime \prime}$ & 115 \\
\hline 3. MS Khust & $48^{\circ} 11^{\prime} 07^{\prime \prime}$ & $23^{\circ} 16^{\prime} 49^{\prime \prime}$ & 166 \\
\hline 4. MS Velykyi Bereznyi & $48^{\circ} 54^{\prime} 05^{\prime \prime}$ & $22^{\circ} 27^{\prime} 19^{\prime \prime}$ & 209 \\
\hline 5. MS Rachiv & $48^{\circ} 03^{\prime} 08^{\prime \prime}$ & $24^{\circ} 12^{\prime} 00^{\prime \prime}$ & 438 \\
\hline 6. MS Mizhhiria & $48^{\circ} 31^{\prime} 26^{\prime \prime}$ & $23^{\circ} 30^{\prime} 23^{\prime \prime}$ & 456 \\
\hline 7. MS Nizhni Vorota & $48^{\circ} 46^{\prime} 30^{\prime \prime}$ & $23^{\circ} 05^{\prime} 49^{\prime \prime}$ & 500 \\
\hline 8. MS Nizhniy Studeny & $48^{\circ} 42^{\prime} 10^{\prime \prime}$ & $23^{\circ} 22^{\prime} 01^{\prime \prime}$ & 615 \\
\hline 9. MS Play & $48^{\circ} 39^{\prime} 59^{\prime \prime}$ & $23^{\circ} 11^{\prime} 49^{\prime \prime}$ & 1330 \\
\hline 10. MS Pozhezhevska & $48^{\circ} 09^{\prime} 14^{\prime \prime}$ & $24^{\circ} 32^{\prime} 03^{\prime \prime}$ & 1439 \\
\hline 11. MP Zalomysko & $48^{\circ} 37^{\prime} 01^{\prime \prime}$ & $23^{\circ} 20^{\prime} 10^{\prime \prime}$ & 785 \\
\hline 12. MP Lozyanske & $48^{\circ} 32^{\prime} 49^{\prime \prime}$ & $23^{\circ} 25^{\prime} 34^{\prime \prime}$ & 572 \\
\hline 13. MP Pylypets & $48^{\circ} 39^{\prime} 45^{\prime \prime}$ & $23^{\circ} 19^{\prime} 20^{\prime \prime}$ & 618 \\
\hline 14. MP Torun & $48^{\circ} 40^{\prime} 23^{\prime \prime}$ & $23^{\circ} 35^{\prime} 07^{\prime \prime}$ & 827 \\
\hline 15. GP Velykyi Bychkiv & $47^{\circ} 58^{\prime} 03^{\prime \prime}$ & $24^{\circ} 00^{\prime} 22^{\prime \prime}$ & 295 \\
\hline 16. GP Verchni Remety & $48^{\circ} 15^{\prime} 44^{\prime \prime}$ & $22^{\circ} 51^{\prime} 30^{\prime \prime}$ & 118 \\
\hline 17. GP Vilok & $48^{\circ} 05^{\prime} 47^{\prime \prime}$ & $22^{\circ} 50^{\prime} 13^{\prime \prime}$ & 114 \\
\hline 18. GP Dovhe & $48^{\circ} 22^{\prime} 00^{\prime \prime}$ & $23^{\circ} 17^{\prime} 08^{\prime \prime}$ & 172 \\
\hline 19. GP Zhornava & $48^{\circ} 59^{\prime} 22^{\prime \prime}$ & $22^{\circ} 37^{\prime} 45^{\prime \prime}$ & 334 \\
\hline 20. GP Zarichevo & $48^{\circ} 46^{\prime} 13^{\prime \prime}$ & $22^{\circ} 29^{\prime} 57^{\prime \prime}$ & 154 \\
\hline 21. GP Znyatsevo & $48^{\circ} 29^{\prime} 28^{\prime \prime}$ & $22^{\circ} 31^{\prime} 03^{\prime \prime}$ & 108 \\
\hline 22. GP Kolochava & $48^{\circ} 25^{\prime} 26^{\prime \prime}$ & $23^{\circ} 42^{\prime} 34^{\prime \prime}$ & 567 \\
\hline 23. GP Lugi & $48^{\circ} 03^{\prime} 47^{\prime \prime}$ & $24^{\circ} 26^{\prime} 15^{\prime \prime}$ & 632 \\
\hline 24. GP Maidan & $48^{\circ} 36^{\prime} 50^{\prime \prime}$ & $23^{\circ} 27^{\prime} 50^{\prime \prime}$ & 503 \\
\hline 25. GP Neresnytsia & $48^{\circ} 06^{\prime} 51^{\prime \prime}$ & $23^{\circ} 46^{\prime} 09^{\prime \prime}$ & 299 \\
\hline 26. GP Pidpolozzia & $48^{\circ} 44^{\prime} 35^{\prime \prime}$ & $23^{\circ} 01^{\prime} 15^{\prime \prime}$ & 362 \\
\hline 27. GP Ruska Mokra & $48^{\circ} 20^{\prime} 39^{\prime \prime}$ & $23^{\circ} 54^{\prime} 33^{\prime \prime}$ & 563 \\
\hline 28. GP Svalyava & $48^{\circ} 33^{\prime} 11^{\prime \prime}$ & $22^{\circ} 58^{\prime} 49^{\prime \prime}$ & 193 \\
\hline 29. GP Simer & $48^{\circ} 44^{\prime} 03^{\prime \prime}$ & $22^{\circ} 30^{\prime} 53^{\prime \prime}$ & 152 \\
\hline 30. GP Tyachiv & $48^{\circ} 00^{\prime} 17^{\prime \prime}$ & $23^{\circ} 34^{\prime} 33^{\prime \prime}$ & 211 \\
\hline 31. GP Ust-Chorna & $48^{\circ} 19^{\prime} 49^{\prime \prime}$ & $23^{\circ} 55^{\prime} 39^{\prime \prime}$ & 529 \\
\hline 32. GP Chop & $48^{\circ} 24^{\prime} 56^{\prime \prime}$ & $22^{\circ} 11^{\prime} 04^{\prime \prime}$ & 101 \\
\hline 33. GP Yasinya & $48^{\circ} 16^{\prime} 21^{\prime \prime}$ & $24^{\circ} 21^{\prime} 31^{\prime \prime}$ & 650 \\
\hline
\end{tabular}

Note: MS - meteorological station, MP - meteorological point, GP - hydrological point 
Natural meteorological phenomena of the II level of danger (NMP II) are natural phenomena that in terms of quantitative indicators, duration, and territory of threat, pose a threat to the population and disrupt the functioning of the economic complex of the country (Humonenko et al., 2019).

Natural meteorological phenomena of the III level of danger (NMP III) are natural phenomena that, according to quantitative indicators, duration, and area of distribution, pose a threat to human life in large areas, lead to large-scale damage to the country's economic complex (Humonenko et al., 2019).

Only those cases of snowfalls were taken into account, which in quantitative and temporal characteristics reached the corresponding values specified in Table 2.

Table 2. Criteria for heavy and extreme snowfalls approved by CGO and UkrHMC from January 1,2019

\begin{tabular}{cc|ccc}
\hline \hline Phenomenon & $\begin{array}{c}\text { Criterion of the natural } \\
\text { phenomenon of the II level of } \\
\text { danger (NMP) } \\
\text { quantitative } \\
\text { indicator }\end{array}$ & duration & Phenomenon & \multicolumn{2}{c}{$\begin{array}{c}\text { Criterion of the natural } \\
\text { phenomenon of the III level of } \\
\text { danger (NMP) } \\
\text { quantitative } \\
\text { indicator }\end{array}$} & duration \\
\hline $\begin{array}{c}\text { heavy } \\
\text { snowfall }\end{array}$ & $20-29 \mathrm{~mm} \quad \leq 12$ hours & $\begin{array}{c}\text { extreme } \\
\text { snowfall }\end{array}$ & $\geq 30 \mathrm{~mm}$ & $\leq 12$ hours \\
\hline
\end{tabular}

Data on heavy and extreme snowfalls were obtained by sampling from various sources of information, thus multiple verifications were performed. The basis of the database was the monthly «Tables of meteorological and agrometeorological observations», which are compiled by all meteorological stations. For meteorological and hydrological points, the information was obtained from the monthly «Tables of meteorological observations», and if they were not available, then from the «Books for recording hydrological observations». The information was also supplemented from the annual «Weather review and natural hydrometeorological phenomena on the territory of Ukraine», from the database METEOBASE developed by UkrHMC, and from «Reports on natural hydrometeorological phenomena» obtained directly from meteorological stations. The single program of meteorological observations of precipitation at stations and observation points made it possible to unify and combine data for research.

Statistical data processing, reliability assessment of the used series of observations, and accuracy testing of the obtained quantity were performed using 
the methods of mathematical statistics (Battalov, 1968; Dubrovskaya and Knyazev, 2011; Kobysheva and Narovlyanskyy, 1978; Shkolnyy et al., 1999).

The calculation of arithmetic mean (perennial) values $(\bar{x})$ was performed by the formula:

$$
\bar{x}=\frac{\sum x_{i}}{n},
$$

where $x_{i}$ are the individual values of the researched feature, $n$ is the the number of years, cases or observations.

To characterize the variability of heavy and extreme snowfalls, the standard deviations of individual values $(\sigma)$ from the long-term average, as well as the coefficients of variability (variation) $\left(C_{v}\right)$ were calculated by the formulas:

$$
\begin{gathered}
\sigma=\sqrt{\frac{\sum\left(x_{i}-\bar{x}\right)^{2}}{n}}, \\
C_{v}=\frac{\sigma}{\bar{x}} .
\end{gathered}
$$

All mathematical calculations of indicators were performed in Microsoft Excel 2016.

Mapping of data on heavy and extreme snowfalls was carried out using the software package for cartographic modeling Surfer 15, and the isoline method was used. Interpolation was performed by the kriging method, as the one that most accurately uses statistical parameters to find the optimal estimate in terms of minimum mean deviation when constructing surfaces, cubes, and maps (Abdullin and Shikhov, 2017; Katsalova and Shpyh, 2013; Mkrtchyan and Schuber, 2013). All cartographic materials are created in an equilateral cylindrical projection of the Mercator using a three-dimensional coordinate system WGS- 84 .

\section{Results}

During 1990-2019, 453 isolated cases of heavy and 125 cases of extreme snowfall were recorded in the research area. The long-term distribution of the number of heavy and extreme snowfalls is shown in Fig. 2. 


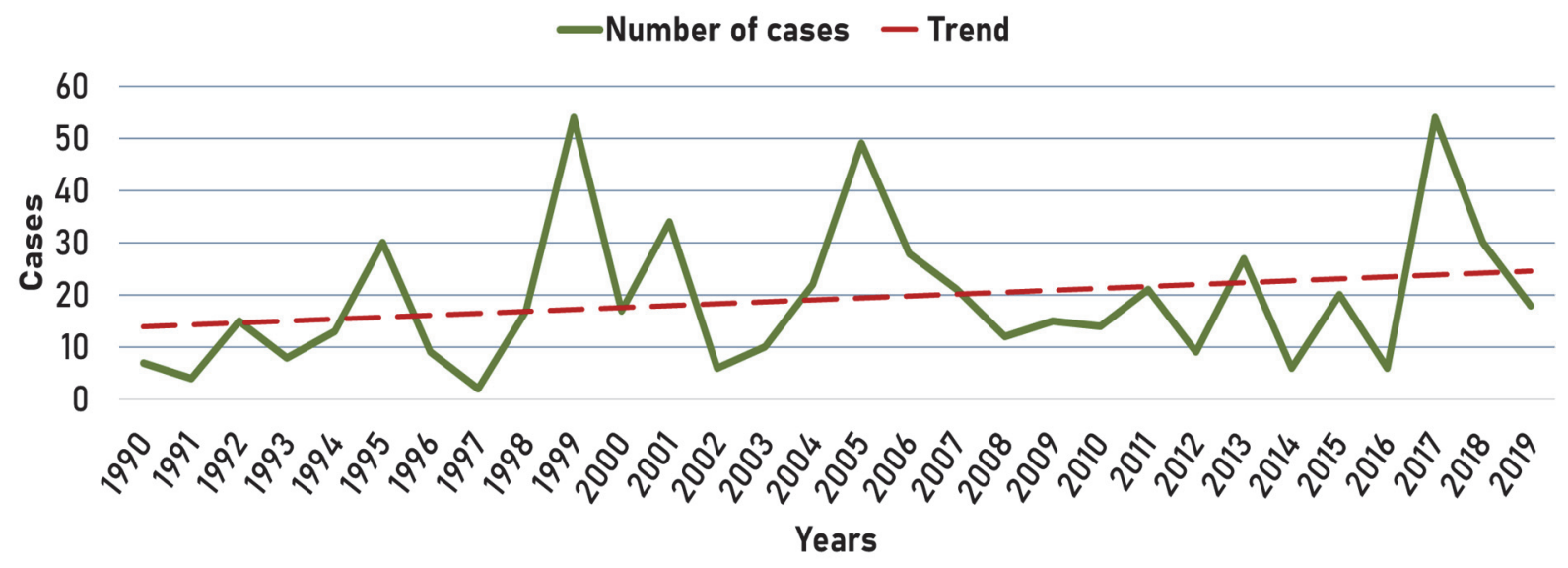

Fig. 2. Total number of cases of heavy and extreme snowfalls

As it can be seen from the graph (Fig. 2), the number of cases varies significantly from year to year. The most heavy and extreme snowfalls were recorded in 1999 and 2017 - 54 cases, and the least number was recorded in 1991 (4 cases) and 1997 ( 2 cases). In the first decade (1990-1999), 159 cases of heavy and extreme snowfalls were recorded, in the second (2000-2009) - 214 cases, and in the third (2010-2019) - 205 cases. The linear trend shows a tendency to increase the number of heavy and extreme snowfalls during the researched period, and therefore their recurrence and frequency increase. The same trends in climate change are observed globally (Pachaury and Mayer, 2014) and regionally (Balabukh, 2013). The average annual recurrence of heavy and extreme snowfalls happened in 19.3 cases, separately heavy snowfalls happened in 15.1 cases, emergency happened in 4.3 cases.

The average amount of precipitation that falls during one snowfall is of great practical importance. Calculations showed that for all cases of the studied snowfalls, an average of $26.6 \mathrm{~mm}$ of snow fell. The standard deviation was $7.7 \mathrm{~mm}$, which indicates a fairly wide range of variation in precipitation during snowfalls. The coefficient of variation was $29 \%$, which conditionally indicates the homogeneity of the sample and the rare recording of extraordinary snowfalls during which $\geq 50 \mathrm{~mm}$ of precipitation falls in $\leq 12$ hours.

To calculate the climatic characteristics, the annual course of heavy and extreme snowfalls is important (Fig. 3). 


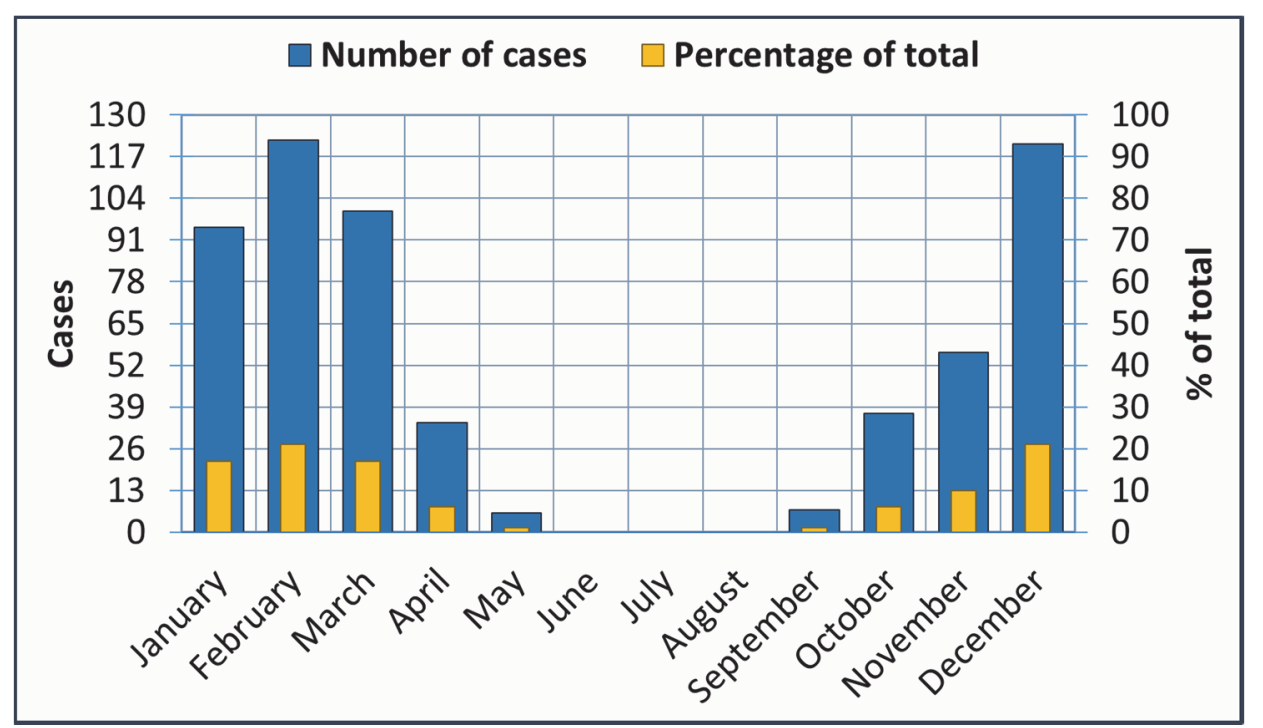

Fig. 3. Annual number of cases and their percentage of the total number of heavy and extreme snowfalls.

Analysis of the diagram (Fig. 3) shows that heavy and extreme snowfall fell during all seasons, except summer. Most of them were in winter: December -121 (20.9\%), January - 95 (16.5\%), and February - 122 (21.1\%) cases. A large number of snowfalls was recorded in March - 100 (17.3\%) cases, which is due to the predominance of winter circulation this month. An interesting fact was that heavy snowfalls were observed even in May -6 cases (1.0\%) and September 7 cases $(1.2 \%)$, and during the warm period of the year (April-October), they were $14.5 \%$ of the total number of cases. The calculated average monthly distribution of cases is given in Table 3. Such distributions indicate the highest probability of heavy and extreme snowfalls in December and February, slightly lower in January and March, low in April, October, and November, and the lowest in May and September.

Table 3. The average monthly number of cases of heavy and extreme snowfalls

\begin{tabular}{ccccccccccccc}
\hline \hline & \multicolumn{11}{c}{ Months } \\
\cline { 2 - 7 } & I & II & III & IV & V & VI & VII & VII & IX & X & XI & XII \\
Cases & 3.2 & 4.1 & 3.3 & 1.1 & 0.2 & - & - & - & 0.2 & 1.2 & 1.9 & 4.0 \\
\hline
\end{tabular}

The duration of snowfall is one of the most important characteristics. The process of snow accumulation and formation of snow cover height depends on it. During heavy snowfalls in the mountains of the Transcarpathian region, an increase in snow cover up to $50 \mathrm{~cm}$ can occur per day, which sharply increases the risk of avalanches (Hryshchenko et al., 2013). The temporal dynamics of the duration of heavy and extreme snowfalls is given in Table. 4. 
Table 4. Distribution of cases of heavy and extreme snowfalls of different duration

\begin{tabular}{cccccccccccc}
\hline \hline \multicolumn{10}{c}{ Duration } \\
to 1 & $\begin{array}{c}\mathbf{1 - 2} \\
\text { hour } \\
\text { hours }\end{array}$ & $\begin{array}{c}\mathbf{2 - 3} \\
\text { hours }\end{array}$ & $\begin{array}{c}\mathbf{3 - 4} \\
\text { hours }\end{array}$ & $\begin{array}{c}\mathbf{4 - 5} \\
\text { hours }\end{array}$ & $\begin{array}{c}\mathbf{5 - 6} \\
\text { hours }\end{array}$ & $\begin{array}{c}\mathbf{6 - 7} \\
\text { hours }\end{array}$ & $\begin{array}{c}\mathbf{7 - 8} \\
\text { hours }\end{array}$ & $\begin{array}{c}\mathbf{8 - 9} \\
\text { hours }\end{array}$ & $\begin{array}{c}\mathbf{9 - 1 0} \\
\text { hours }\end{array}$ & $\begin{array}{c}\mathbf{1 0 - 1 1} \\
\text { hours }\end{array}$ & $\begin{array}{c}\mathbf{1 1 - 1 2} \\
\text { hours }\end{array}$ \\
\hline \multicolumn{10}{c}{} & \multicolumn{10}{c}{ Number of cases } \\
\hline \hline 2 & 1 & 2 & - & 2 & 2 & 4 & 4 & 8 & 9 & 12 & 532 \\
\hline
\end{tabular}

The uneven distribution of the duration of heavy and extreme snowfalls proves that in the territory of Transcarpathia, this natural meteorological phenomena are practically impossible to form, in a relatively short time interval (1-5 hours). However, the transience and discretion of snowfalls make it impossible to accurately record their duration, especially at night. Therefore, this conclusion is, to some extent, relative.

The spatial distribution of the researched snowfalls is of practical importance for the engineering design of buildings and structures, and other needs of various sectors of the national economy. For this purpose, the territory of Transcarpathia was mapped according to various indicators of distribution of heavy and extreme snowfalls. Fig. 4 shows the general picture of the distribution of recurrence of heavy and extreme snowfalls during the researched period.

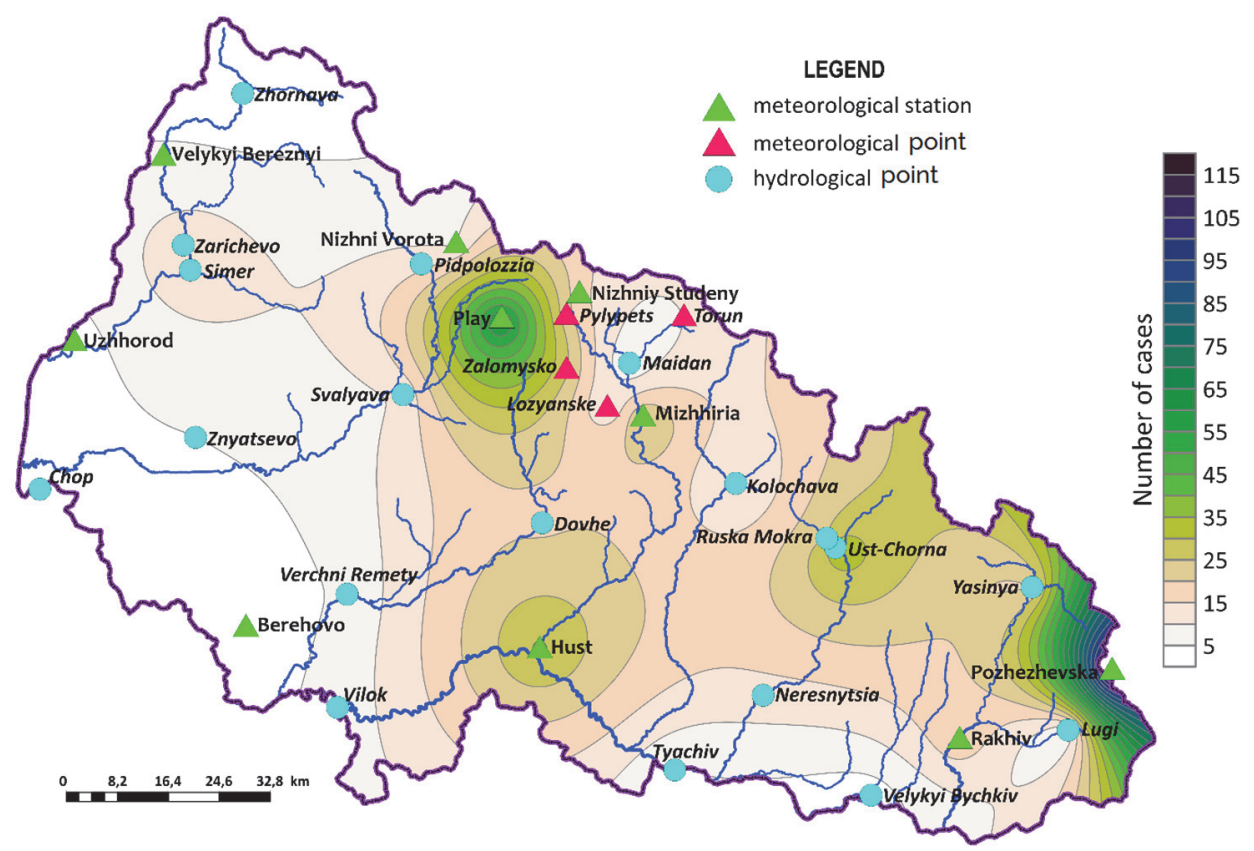

Fig. 4. Recurrence of heavy and constant snowfalls in Transcarpathia in the period of 1990-2019. 
The map clearly distinguishes two zones of maximum recurrence: the territory of the mountain range Chornohora (snow avalanche station Pozhezhevska - 121 cases in 30 years) and the mountain range Borzhava (snow avalanche station Play - 62 cases in 30 years). Two more, less pronounced zones of significant recurrence are the upper left bank of the Teresva River basin (hydrological points Ust-Chorna - 34 cases and Ruska Mokra - 25 cases) and the catchment area of the Tysa and Rika rivers (meteorological station Khust 31 cases).

The lowest recurrence is observed in the Transcarpathian lowland, which is part of the Middle Danube lowland (Uzhhorod aviation meteorological station 3 cases, Beregovo meteorological station -2 cases, and Chop hydrological point -4 cases). Other zones of recurrence minima are the upper reaches of the Uzh River (Zhornava hydrological point - 1 case) and the estuaries of the Kosivska and Shopurka rivers (Velykyi Bychkiv hydrological point -2 cases). In the rest of the territory, the recurrence rates, on average, vary from 10 to 20 cases over 30 years.

The next step was to map the quantitative indicators, i.e., the average and maximum values of precipitation during snowfall, recorded for each observation point (Fig. 5).

From Fig. 5(b) it is clear, that during one snowfall twice as much precipitation may fall as it is usually the case on average. In Fig. 5 (a) the following zones of maximum precipitation values are distinguished: the upper parts of the Teresva, Terebli, and Rika river basins (Ruska Mokra hydrological point $-30.8 \mathrm{~mm}$ and meteorological points: Lozianske $-30.2 \mathrm{~mm}$, Pylypets $30.9 \mathrm{~mm}$ and Torun $-32.0 \mathrm{~mm}$ ). It can be concluded that in these areas there are often extraordinary snowfalls, which are classified as natural meteorological phenomena of the highest III level of danger (Table 2). Areas of least risk of emergency snowfall are the right part of the Uzh River basin, the Verkhnyotysianska basin and the southern part of the Transcarpathian lowland.

Regarding the maximum amount of precipitation during snowfall (Fig. 5 (b)), the distribution is slightly different. There are two distinct zones of maximum precipitation: the Borzhava mountain range and the upper reaches of the Teresva River. During the researched period, a record amount of precipitation during an extreme snowfall was recorded at the avalanche station Play (Borzhava ridge) on the night of January $18-19,2007-71.3 \mathrm{~mm} / 7$ hours $10 \mathrm{~min}$. Another zone of maximum precipitation is the ridge of Chornohora in the eastern part of Transcarpathia (avalanche station Pozhezhevska - March 4-5, 2001 $54.3 \mathrm{~mm} / 12$ hours). Areas where extreme snowfalls have never been recorded are the upper right part of the Uzh River basin, the southwestern part of the Transcarpathian lowland, and the eastern half of the Verkhnotysianska basin. 


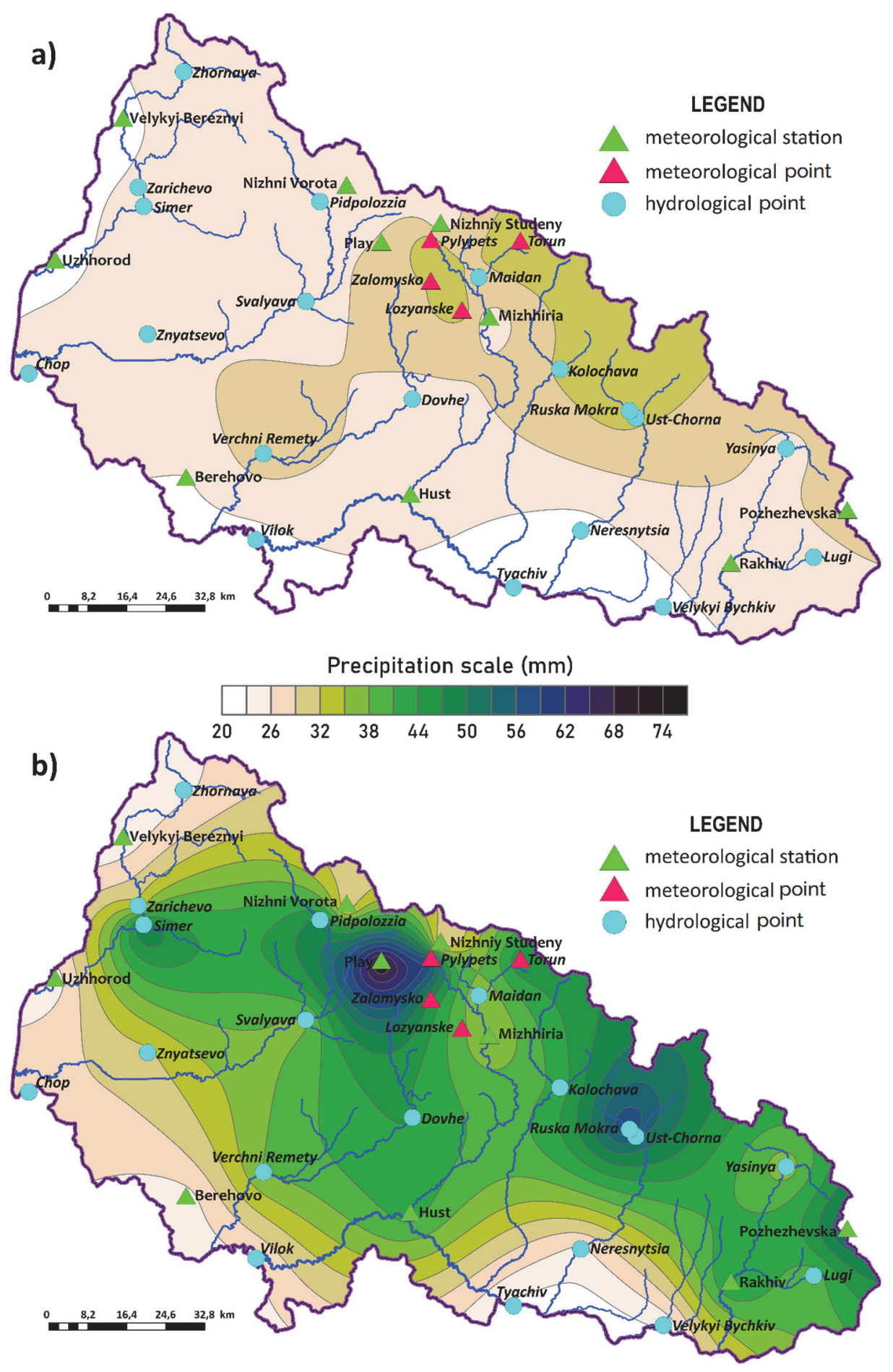

Fig. 5. Average annual (a) and maximum (b) precipitation of heavy and extreme snowfalls in Transcarpathia in the period of 1990-2019. 


\section{Conclusions}

1. A positive trend in the number of heavy and extreme snowfalls in the Transcarpathian region for the period 1990-2019 has been identified. It is possible that in the future we should expect an increase in the number of cases of heavy and extreme snowfalls.

2. The average annual recurrence of heavy and extreme snowfalls during 19902019 was determined - 19.3 cases, i.e., on average, about 19 local cases of heavy and extreme snowfalls were observed in the Transcarpatian region a year.

3. When compiling the review of weather-forming processes, it is recommended to take into account the features of the annual course of the formation of heavy and extreme snowfalls, which has a maximum in February and December.

4. Over Transcarpathia, heavy and extreme snowfalls most often (92\%) last 1112 hours, falling $50 \mathrm{~mm}$ of snow in a shorter time interval is less likely.

5. The areas of the greatest natural load by heavy and extreme snowfalls due to mapping of the territory of the Transcarpathian region are selected - these are the territory of the Borzhava mountain range, the upper reaches of the Teresva River, and the Chornohora mountain range.

6. It is established, that the greatest recurrence of heavy and extreme snowfalls was observed in the mountainous part of the Transcarpathian region (on average $15-25$ cases per year). The maximum amount of precipitation in the mountains during snowfalls varies between $25-35 \mathrm{~mm}$. Extreme snowfalls, during which $\geq 50 \mathrm{~mm}$ of precipitation falls in $\leq 12 \mathrm{~h}$, are a rare natural meteorological phenomenon.

For a more detailed study of heavy and extreme snowfalls as natural meteorological phenomena in the Transcarpathian region, it is advisable to conduct cluster analysis, and regression and correlation analyzes of their relationship with orography.

\section{References}

Abdullin, R.K. and Shikhov, A.N., 2017: Sinteticheskoye kartografirovaniye opasnykh meteorologicheskikh yavleniy na regionalnom urovne. Geodeziya i Kartografiya 78, 31-40. (In Russian)

Acar, Z. and Gönençgil, B., 2019: Extreme precipitation events in Turkey. Meteorologický časopis 22, $87-94$.

Babychenko, V.M. and Dyachuk, V.A., 2003: Klimat Ukrayiny. UkrNDHMI, Kyyiv. (In Ukrainian)

Babychenko, V.N., 1991: Stykhyynye meteorolohycheskye yavlenyya na Ukraine i v Moldavyi. Hydrometeoyzdat, Lenynhrad. (In Russian)

Balabukh, V.O., 2008: Minlyvist duzhe sylnykh doshchiv i sylnykh zlyv v Ukrayini. Naukovi pratsi UkrNDHMI 257, 61-72. (In Ukrainian) 
Balabukh, V.O., 2013: Rehionalni proyavy hlobalnoyi zminy klimatu v Zakarpatskiy oblasti. Ukrayinskyy hidrometeorolohichnyy zhurnal 13, 55-62. (In Ukrainian)

Barry, R.H., 1984: Pohoda y klymat v horakh. Hydrometeoyzdat, Lenynhrad. (In Russian)

Battalov, F.Z., 1968: Mnoholetnye kolebanyya atmosfernykh osadkov y vychyslenye norm osadkov. Hydrometeoyzdat, Lenynhrad. (In Russian)

Dubrovskaya, L.Y. and Knyazev, H.B., 2011: Kompyuternaya obrabotka estestvenno-nauchnykh dannykh metodamy mnohomernoy prykladnoy statystyky. TML-Press, Tomsk. (In Russian)

Herenchuk K.I., 1981: Pryroda Zakarpatskoyi oblasti. Vyshcha shkola, Lviv. (In Ukrainian)

Hryshchenko V.F., Aksyuk O.M., and Honcharenko H.A., 2013: Dovidnyk zi snihovoho pokryvu v horakh Ukrayiny (Karpaty, Krym). UkrNDHMI, Kyyiv. (In Ukrainian)

Humonenko, L.V., Zhuk, N.H., Savchenko, L.I., Tkach, L.V., and Filonenko, V.O., 2019: Nastanova z meteorolohichnoho prohnozuvannya. UkrHMTS, Kyyiv. (In Ukrainian)

Katsalova, L.M. and Shpyh, V.M., 2013: Krihinh-interpolyatsiya v zadachakh prohnozu pohody. Naukovi pratsi UkrNDHMI 264, 3-9. (In Ukrainian)

Kobysheva, N.V., Narovlyanskyy, H.YA., 1978: Klymatolohycheskaya obrabotka meteorolohycheskoy ynformatsyy. Hydrometeoyzdat, Lenynhrad. (In Russian)

Lipinskyy, V.M., Osadchyy, V.I., and Babychenko, V.M., 2006: Stykhiyni meteorolohichni yavyshcha na terytoriyi Ukrayiny za ostannye dvadtsyatyrichchya (1986-2005 rr.). Nika-Tsentr, Kyyiv. (In Ukrainian)

Lohvynov, K.T., Babychenko, V.N., and Kulakovskaya, M.YU., 1972: Opasnye yavlenyya pohody na Ukrayne. Hydrometeoyzdat, Lenynhrad. (In Russian)

Lohvynov, K.T., Raevskyy, A.N., and Ayzenberh, M.M., 1973: Opasnye hydrometeorolohycheskye yavlenyya v Ukraynskykh Karpatakh. Hydrometeoyzdat, Lenynhrad. (In Russian)

Lukić, T., Basarin, B., Micić, T., Bjelajac, D., Maris, T., Marković, S.B., Pavić, D., Gavrilov, M.B., and Mesaroš, M., 2018: Rainfall erosivity and extreme precipitation in the Netherlands. Idöjárás 122, 409-432. https://doi.org/10.28974/idojaras.2018.4.4

Mkrtchyan, O.S. and Shuber, P.M., 2013: Interpolyatsiya danykh meteosposterezhen' kil'kostey opadiv ta inshykh klimatychnykh zminnykh metodom rehresiynoho krygingu. Visnyk Lvivskoho universytetu. Seriya heohrafichna 42, 258-264. (In Ukrainian)

Osadchyy, V.I. and Babychenko, V.M., 2012: Dynamika stykhiynykh meteorolohichnykh yavyshch v Ukrayini. Ukrayinskyy heohrafichnyy zhurnal 4, 8-14. (In Ukrainian)

Pachaury, R.K. and Mayer, L.A., 2014: Yzmenenye klymata: Obobshchayushchyy doklad. Vklad Rabochykh hrupp I, II y III v Pyatyy otsenochnyy doklad Mezhpravytelstvennoy hruppy ekspertov po yzmenenyyu klymata. MHEYK, Zheneva. (In Russian)

Popov, T., Gnjato, S., and Trbic, G., 2018: Analysis of extreme precipitation over the Peripannonian region of Bosnia Hercegovina. Idöjárás 122, 433-452. https://doi.org/10.28974/idojaras.2018.4.5

Pyasetska, S.I., 2001: Chyslo dniv iz sylnymy opadamy v pivdenno-zakhidniy chastyni Krymskykh hir. Naukovi pratsi UkrNDHMI 249, 73-81. (In Ukrainian)

Radzka. E. and Rymuza. K., 2020: Statistical and geostatistical analysis of spatial variation of precipitation periodicity in the growing season. Időjárás 124, 129-141. https://doi.org/10.28974/idojaras.2020.1.7

Rishko, S.V., 2017: Dopovid pro stan navkolyshnoho pryrodnoho seredovyshcha Zakarpatskoyi oblasti za 2016 rik. Departament ekolohiyi ta pryrodnykh resursiv Zakarpatskoyi ODA, Uzhhorod. (In Ukrainian)

Sakaly, L.Y., 1985: Teplovoy y vodnyy rezhym Ukraynskykh Karpat. Hydrometeoyzdat, Lenynhrad. (In Russian)

Shkolnyy, YE.P., Loyeva, I.D., and Honcharova, L.D., 1999: Obrobka ta analiz hidrometeorolohichnoyi informatsiyi. Odeskyy hidrometeorolohichnyy instytut, Odesa. (In Ukrainian)

Tykhomyrova, YE.B., 2018: Zmina klimatu yak skladova mizhnarodnykh prohram bezpeky. Visnyk Lvivskoho universytetu. Seriya mizhnarodni vidnosyny 44, 22-31. (In Ukrainian)

Voloshyna, O.V. and Knysh, I.F., 2010: Statystychne doslidzhennya vypadkiv duzhe sylnykh doshchiv na terytoriyi Zakhidnoyi Ukrayiny. Ukrayinskyy hidrometeorolohichnyy zhurnal 6, 102-108. (In Ukrainian) 